\title{
CRÁTILO, ISIDORO Y JACLAQUE: LA ETIMOLOGÍA Y EL NEOLOGISMO \\ COMO MECANISMOS DE REAPROPIACIÓN DE LA LENGUA Javier Martínez Villarroya*
}

¿No sabes que sobre el río de Troya, el que sostuvo combate singular con Hefesto, dice Homero: al que los dioses llaman Janto y los hombres Escamadro?

Platón, Crátilo, 391d

Esto no es un cuento. Y al mismo tiempo es un cuento: el de Crátilo, Isidoro y Jaclaque.

Todos tenemos, en algunos momentos de nuestra vida y en algunos rincones de nuestra alma, manías: calzarnos primero el zapato derecho, comer estrictamente a la misma hora, acudir al baño antes de una reunión, sortear la juntura de dos baldosas... Hoy, cuando esas manías se acumulan y se acumulan tanto que nos obligan a buscar ayuda, el médico tiene un nombre para designar nuestro estado: "trastorno obsesivo compulsivo". Toc-toc. Y con el verbo, Dios creó el mundo. Y con el nombre el psicólogo creó la enfermedad. " "Toc-toc, he llegado", dice el TOC.

En mi caso, tengo una manía desde la adolescencia que me puedo permitir compartir aquí, pues es seudoacadémica, intelectual e, incluso, ante una audiencia de jóvenes alumnos con la vida por delante, puede parecer elegante: tengo la obsesión de inventarme etimologías.

No tengo que pensar demasiado para acordarme del último episodio. Fue aproximadamente hace tres semanas. Llegaba al salón de clase, clase repleta, repensando mi estrategia expositiva: "Debo explicarles lo que es una reseña crítica. Debo lograr que entiendan la idea". "Ex-plicar", para mí, es "extraer los pliegues", "abrir las plicas", es decir, que cuando

* Departamento Académico de Lenguas, ITAM.

${ }^{1} \mathrm{Al}$ respecto, véase el estudio de Michel Foucault, Historia de la locura en la época clásica, 2015, México, FCE. 
DOSSIER

entro al salón de clases lo que pienso es que debo "des-plegar" ideas. Como sabemos, cuando uno tiene una obsesión no hace más que encontrar razones y más razones para justificarla. Si explicar es desplegar — pienso_- "en-tender" algo debe de consistir en ser capaz de "tender en" nuestro fuero interno esas ideas que el maestro desplegó como brillantes ropas ante nosotros. Las obsesiones se pegan como el chicle a los zapatos, y cuando creemos que por fin nos hemos liberado de ellas, vuelven. La palabra "idea", les digo a mis alumnos, está obviamente emparentada con "ídolo” e "idolatría”. Un ídolo, según la RAE, es la "imagen de una deidad objeto de culto"2 y, por ende, la idolatría es la adoración de imágenes. "Repiensen pues — les digo a mis alumnosel mito de la caverna", porque quizás no describe una oscura cueva de la que los seres inteligentes son capaces de escapar pensando conceptos y nociones inmutables. Por el contrario, quizás ese mito alude a un lugar en donde el iniciado "ve" las "imágenes" fundamentales, es decir, una especie de templo en donde el agraciado goza de la revelación (el corolario de este argumento es, por un lado, que ese lugar es el verdadero templo en donde las imágenes fundamentales se "con-templan"; por otro, que la teoría de Platón bien podría ser calificada de idolatría). Quien padece una obsesión, por si fuera poco, quiere que su obsesión se universalice, contagiar a amigos, familiares y colegas, y ese es el motivo por el que en la clase de hace tres semanas les propuse a mis alumnos -he logrado algunos conversos - que hiciéramos "etimología ficción". “¿De dónde provienen los vocablos 'reseña crítica'?”, pregunto. La conclusión a la que, gracias a la mayéutica y a la maña, logramos llegar en clase es la siguiente: "re-señar" es "indicar las señas de algo" y "criticar" tiene la misma raíz que "cribar". En consecuencia, la tarea de la semana, la elaboración de una reseña crítica, queda reformulada así: elaboren para dentro de quince días "un mapa sobre el libro mencionado para que el viajero novato pueda adentrarse en su territorio y discernir en él entre el oro y la arena. Escriban las señas imprescindibles que necesita el nuevo lector para no confundir la paja y el grano”. Así son las manías.

${ }^{2}$ Real Academia Española, "Ídolo", en $<$ http://dle.rae.es/?id=Kv2nxNm>, consultado el 28 de septiembre de 2018 . 
Es reconfortante descubrir (y difícil no sortear la juntura de la baldosa: "des-cubrir" significa "quitar el velo que cubre la verdad", etimología que en este caso coincide con la dada por Martin Heidegger para la palabra griega que nosotros traducimos habitualmente como "verdad" y él siempre como "desvelamiento")... ${ }^{3}$ Es reconfortante descubrir - decía - que la costumbre de imaginar el significado propio de las palabras, modificándolas si hace falta, es muy vieja y que, de un modo u otro, se mantiene viva.

Sin lugar a dudas, el Crátilo platónico es la referencia obligada para todo aquel interesado (u obsesionado) en el asunto. Ahí, Platón pone a dialogar a Sócrates, Hermógenes y Crátilo en torno al origen de los nombres. ¿Los nombres de las cosas son convenciones y, por tanto, tienen una relación arbitraria con las cosas que designan o, por el contrario, los nombres tienen un vínculo natural con esas cosas designadas? La cuestión no es baladí, pues de su respuesta se derivan problemas epistemológicos de máxima relevancia para la filosofía, ya que "el nombre es un instrumento propio para enseñar y distinguir los seres, como la lanzadera es propia para distinguir los hilos del tejido". ${ }^{4}$

El interesado en la etimología releerá una y otra vez la parte del diálogo en la que un Sócrates inspirado por las Musas ilustra a Hermógenes con el origen (para los especialistas a menudo inventado) de nombres y palabras centrales del mundo griego. ${ }^{5}$ Agamenón es "el de admirable perseverancia"; Orestes, "el montaraz"; Tántalo, "el mayor sufridor"; Zeus, "el que da vida"; la palabra "héroe" tiene que ver con la génesis del amor (eros) o con "aquellos capaces de preguntar" (es decir, que según Platón aquí y contra lo que en otros lados escribe sobre los sofistas, los más habilidosos oradores son los verdaderos héroes);

${ }^{3}$ En español también podría ser "desocultamiento". Vale la pena destacar dos de sus textos al respecto, aunque la doctora Pasternac no sea devota del filósofo alemán: "El origen de la obra de arte", en Caminos del bosque, 1996, Madrid, Alianza, y "Aletheia (Heráclito, fragmento 16)", en Conferencias y artículos, 2001, Barcelona, Del Serbal.

${ }^{4}$ Platón, Crátilo, 388 b. En este pasaje tomé la traducción de Porrúa (Platón, Diálogos, 1984, México, Porrúa). La de Gredos dice: "el nombre es un cierto instrumento para enseñar y distinguir la esencia, como la lanzadera lo es del tejido" (Platón, Diálogos II, 2000, Madrid, Gredos, trad. de J. L. Calvo). En los demás pasajes tomo la traducción de Gredos.

${ }^{5}$ Ibid., 391d-421c. 
DOSSIER

"hombre" (anthropos) significa "el que examina lo que ha visto" o "el que examina al ver", y esto es precisamente lo que distingue a los seres humanos del resto de animales; la palabra "alma" (psique) guarda en su nombre la reminiscencia de su función primordial, que es la de "refrescar" al cuerpo y hacerlo respirar; "cuerpo" (soma) se parece fuertemente a "tumba" (sema) y "signo" (sema), lo que hace tentador pensar que el cuerpo es la tumba del alma y que el cuerpo es signo del alma (porque el alma se manifiesta a través del cuerpo). Sin embargo, Sócrates prefiere vincular "cuerpo" con "prisión" (soma), como hacen Orfeo y sus seguidores, pues el cuerpo es la prisión en donde el alma expía sus culpas hasta lograr liberarse de la rueda de las reencarnaciones. Los nombres de los dioses tampoco escapan al análisis platónico, aunque bien es cierto que el filósofo aclara, antes de proponer nada, que ningún hombre puede pretender saber más que los dioses (no quiere Platón padecer su venganza). Entre las explicaciones destaca, sin duda, las de los nombres del dios del inframundo, Hades Plutón: Hades alude a lo $a$-idea, es decir, a lo que no tiene imagen alguna, lo invisible, que es aquello con lo que nos toparemos al morir (por eso los cátaros dirán siglos después que si no eres capaz de salir de la realidad y ver el mundo de las ideas verdaderas vives muerto, muerto vives sin ver las imágenes verdaderas). Plutón tiene que ver con las "riquezas" que el dios de los muertos atesora. En un fabuloso excurso al respecto, el maestro de Aristóteles cuenta que los seres humanos hacemos las cosas o por necesidad o por deseo, y que el deseo es siempre más fuerte que la necesidad. En consecuencia, hay que pensar que los muertos no escapan del Hades porque Hades los mantiene ahí por la fuerza, sino que los mantiene ahí hechizados con hermosos relatos, dice Platón, pues "este dios es cumplido sofista". ${ }^{6}$ También para nosotros el dios del inframundo, el diablo, es un excelente sofista, pues fue él quien persuadió a Eva de que persuadiera a Adán. Ahora se entiende mejor por qué Platón dice que los verdaderos héroes son los grandes oradores: como Orfeo, son capaces de mantener a raya al diablo dialogando.

Alguien obsesionado con las etimologías podría, incluso, hablar de las de Isidoro y pasar por alto en el homenaje a la eminente profesora

${ }^{6}$ Ibid., $403 \mathrm{~d}$. 
de redacción las fundamentales aportaciones del santo a la puntuación moderna: rescatando a Aristófanes del olvido - al bibliotecario de Alejandría, no al cómico de la Asamblea de las mujeres-, san Isidoro utiliza el punto bajo como pausa breve, el medio como pausa media y el alto como pausa larga. ${ }^{7}$ Pero san Isidoro es célebre, sobre todo, por sus Etimologías (Etymologiae u Originum sive etymologiarum libri viginti), un compendio del saber medieval escrito en el siglo VII en la península ibérica, unas décadas antes de la invasión musulmana. El título del texto general se debe al título del libro diez (de los veinte que tiene la obra en su totalidad), propiamente una serie de etimologías. Sin embargo, es menester que el lingüista le preste atención también a otros libros, como por ejemplo al nueve, que es una especie de prólogo al siguiente en el cual el santo apunta cuestiones generales sobre la lengua. Isidoro defiende que conocer el origen de las palabras es una práctica antigua y fundamental: antigua porque de ella ya hablaron Aristóteles (que la llamaba sýmbolon) y Cicerón (que la llamaba "notación"); y fundamental porque "a menudo este conocimiento es necesario emplearlo para la interpretación de la palabra. Pues tan pronto como adivinas de dónde procede el nombre, entiendes cuál es su fuerza. En efecto, es más fácil la averiguación de cualquier cosa en cuanto conoces la etimología" ${ }^{8}$ Por tales razones, Isidoro de Sevilla, como Sócrates antes (en el Crátilo) y fray Luis de León después (en De los nombres de Cristo), indaga incluso el significado original y pleno de importantes entidades espirituales, en su caso cristianas: ángel significa "enviado"; arcángel, “enviado principal"; Gabriel, "fortaleza de Dios"; Rafael, "curación o medicina de Dios"; Adán, "tierra roja"; etc. ${ }^{9}$

Por una razón parecida, Leibniz conminaba a estudiar historia a través de la etimología, pues "cada vez que nos topamos con una sonoridad

${ }^{7}$ Véase, por ejemplo, Daniel R. Esparza, "El origen de los signos de puntuación: una historia que va de Alejandría a Sevilla", Aleteia, 18 de julio de 2016, en <https://es.aleteia.org/2016/07/18/ el-origen-de-los-signos-de-puntuacion-una-historia-que-va-de-alejandria-a-sevilla/ $>$, consultado el 24 de septiembre de 2018.

${ }^{8}$ Isidoro, Etim. ix, 39. Trad. de Mariano Arnal, en $<$ http://www.elalmanaque.com/etimologias/ etimo1.htm>, consultado el 24 de septiembre de 2018.

${ }^{9} \mathrm{Ibid}$., vii. Sobre el nombre de Adán, es muy interesante el siguiente texto: René Guénon, “Algunas observaciones sobre el nombre de Adán”, en Formes traditionnelles et cycles cosmiques, 1989, París, Gallimard. 
DOSSIER

idéntica o parecida, común a bretones, germanos, latinos, griegos, sármatas, fineses, tártaros o árabes, nos hallamos ante un vestigio de lengua antigua común". ${ }^{10}$ La etimología, pues, nos acercaría a lo que tienen en común todas las lenguas, a una especie de protolengua o lengua primitiva que, con permiso de Chomsky, ya Leibniz apuntó que debía mostrarnos con mayor claridad la conexión existente entre las cosas. En último término, la labor del etimólogo acaba cuando encuentra la onomatopeya que se oculta tras la palabra: "Los primeros orígenes de los nombres se descubren cada vez que podemos remontarnos hasta la raíz de la onomatopeya". ${ }^{11}$ En el fondo, creo, el obsesionado con las etimologías tiene fe en que las palabras existen no solo para ser oídas, sino también y especialmente para ser sentidas (es probable que aquí peque de etnocentrismo, pues en catalán hay un único verbo para decir sentir y oír: "sentir").

Al fin, pues, llegamos a lo que debía ser el núcleo de este texto y que sin embargo mutó en corolario: un inconsciente paseo por Comentarios a neologismos de Jacques Lacan. ${ }^{12}$ En este libro, escrito a cuatro manos, dos cerebros y un corazón, Marcelo y Nora Pasternac traducen muchos de los sugerentes neologismos que Jacques Lacan inventó. Al concebirlos, el psicoanalista buscaba, como los que lo antecedieron, encontrar un "sentido" más pleno que permitiera no solo oír, sino también "sentir" tales palabras. Y así, sus neologismos yo los siento gemelos de las antiguas etimologías, pues “in-vestigar” el verdadero significado de algo debe significar precisamente "sumergirse en los vestigios" del pasado. El estudio de las etimologías, la creación de neologismos y los ejercicios de etimología ficción exigen, me parece, una maravillosa tarea que a todos nos incumbe y que sin embargo frecuentemente delegamos en el poeta: la labor de reinventar la "propia" lengua, es decir, la labor de "reapropiárnosla".

${ }^{10}$ Leibniz, Opera Omnia, ed. L. Dutens, Col. IV ii, Olms, Berlín, 1889, p. 188 (citado y traducido por Fabio Vélez, Antes de Babel. Una historia retórica de la traducción, 2016, Granada, Comares, p. 21).

${ }^{11}$ Ibid., p. 24.

${ }^{12}$ Marcelo Pasternac y Nora Pasternac, Comentarios a neologismos de Jacques Lacan, 2003, México, École lacanniene de psychanalyse. 
No tenía mucho sentido que, para presentar el libro de Nora y Marcelo y rescatar algunas de sus maravillosas traducciones, escribiera sobre los lacanianos (no soy perito en el asunto). Sí, sin embargo, tiene sentido que escriba para los lacanianos, es decir, para que me lean ellos no como a un colega que dialoga, sino como a un paciente con toc-toc, y dejar aquí pues un hipotético estudio de caso. ¿Qué quiero decir? Pues que a los lacanianos lo que les interesa es escuchar cómo relatamos nuestros relatos y no tanto qué relatamos en ellos (en eso, curiosamente, se parecen bastante a los profesores de redacción). Así, pues, es como debe acabar este relato: con la reapropiación de los neologismos de Lacan traducidos por los Pasternac por un neófito obsesivo por las etimologías. Con el juego.

Jaclaque no dejaba de lluviar. Desde que le habían pedido kantificarlo todo, la omprisión del babysmo occidental y piagético lo estaba heterizando. Se arrastraba polifémico con su mierduelo. ¿Alfabestiazar —se preguntaba — es mi misión? Leía foliasofía en las noches cuadrucéfalas, pero de ella solo extraía argumentos faloaces, tal era el parasexual estado en el que el principalesco serestando se encontraba... y más y más turbación padecía cuando pensaba en la exagerada puntoficación de su última hablancia... Y así se automorficaba... Y así se tomía... A veces, compungido por el miedo, actuaba como orinomante de madrugada. "Cosicar las acosas, eso necesito, y afreudiarme. ¡Menos televisionar y más faunéticos bosques para escapar del saber histoérico!". Quizás entonces, en las cumbres y simas de la otrificación, la amierda desaparezca, el nhombre verdadero resucite y vuelva a existierrir sobre la tierra. "He oído la clamación", fonaba. "He sentido el placerógeno", mediecía. "He visto el unoenmás", cosmografiaba. "Otrificar en lo femil es el camino para almar", avisionaba. Así se aturdecía Jaclaque el almoroso... ${ }^{13}$

Me gustaría saber qué opinaría Marcelo de semejante relato, pero me cuenta Nora que en la consulta no opinaba, tan solo interrumpía al

${ }^{13}$ Me he tomado la libertad de "traducir" algunos de los términos para los que los Pasternac no proponen traducción y sí comentario de este cuento. La mayoría, sin embargo, son traducciones suyas, aunque a veces conjugadas y declinadas por mí. 
Se prohíbe su reproducción total o parcial por cualquier medio, incluido electrónico, sin permiso previo y por escrito de los editores.

DOSSIER

paciente en el momento clave, para que se quedara reflexionando sobre lo que necesitaba reflexionar. ¿En qué momento me habría cortado y me habría dicho "La sesión de hoy ha acabado"?

Jaclaque el almoroso... 